\title{
MAPPING OF AGRICULTURAL LANDS IN FLOOD HAZARD AREAS IN HULU SUNGAI TENGAH REGENCY, SOUTH KALIMANTAN
}

\author{
Salamiah ${ }^{1}$, Rosalina Kumalawati ${ }^{2}$ \\ ${ }^{1}$ Agricultural Faculty, Lambung Mangkurat University \\ Banjarbaru, South Kalimantan, Indonesia \\ ${ }^{2}$ Department of Geography Education, Faculty of Teacher Training and Pedagogy \\ Lambung Mangkurat University, Banjarmasin, South Kalimantan, Indonesia \\ E-mail: rosalinaunlam@gmail.com
}

\begin{abstract}
Floods are natural disasters that frequently hit several developed and developing countries including Indonesia every wet season. Floods also occur in agricultural lands. The purpose of this study was to map the agricultural lands in flood hazard areas in Hulu Sungai Tengah Regency, South Kalimantan Province. Data collecting methods used were field research and literature (library research). Data were analyzed using quantitative and qualitative approaches (mixed methods), with the techniques of scoring, SWOT, and spatial analysis (ArcView 3.2 software). Flood hazard levels of most areas in Hulu Sungai Tengah were categorized into no hazard $\left(957.36 \mathrm{~km}^{2}\right)$, low hazard $\left(243.82 \mathrm{~km}^{2}\right)$, medium hazard $\left(455.01 \mathrm{~km}^{2}\right)$, and high hazard $\left(114.91 \mathrm{~km}^{2}\right)$. The use of agricultural lands for rice fields in Hulu Sungai Tengah were located in all subdistricts and flood hazard areas.
\end{abstract}

Keywords: agriculture, flood, hazard, land

\section{INTRODUCTION}

Floods are natural disasters that frequently hit several developed and developing countries including Indonesia every wet season (Tondobala 2011; Indrianawati and Hakim, 2013). The frequency of flood in the future will increase and its impact will be more severe (UNHabitat 2009; Sakijege, 2013; koye and Ojeh,
2015). The greater impact of floods from year to year can be seen from two perspectives, namely human safety (loss of life or injury) and property damage (loss of property, damage to housing, agriculture) (Septriyadi and Hamhaber, 2013; Widiarto and Kingma, 2014). For example, floods in Hulu Sungai Tengah, South Kalimantan (see Table 1).

The main problem occurred in the study area was that the floods occurred in densely populated areas and farmlands. The agricultural sector has an important role in the economy and the survival of the community, particularly its contribution to employment and domestic food. Agriculture is an integral part of regional development. Agriculture has two benefits to the poor, namely creating alternative employment and creating better access to food. Galuh (2013) and Beatly (2000) argued that nowadays the world is facing three major problems, among others the growing demand for food, population growth, and ecological degradation. The development of food crops is now so closely associated with the problem of utilization of land, changing of agricultural land use which would threaten the width of agricultural production lands along with the increasing of regional development. The growing need for life and good agricultural land uses for the purposes of agricultural production and uses in other fields requires plannings and decision making policies for the most optimal utilization (Kubelaborbir, 2010). 
Table 1 Floods Data in Hulu Sungai Tengah Regency, Year 2015

\begin{tabular}{|c|c|c|c|c|}
\hline No & Village/subdistrict & $\begin{array}{c}\text { Number of } \\
\text { family }\end{array}$ & $\begin{array}{l}\text { Number of } \\
\text { inhabitants }\end{array}$ & Number of victims \\
\hline \multicolumn{5}{|c|}{ Haruyan subdistrict } \\
\hline 1 & Haruyan & 167 & 678 & \\
\hline 2 & Haruyan seberang & 257 & 928 & \\
\hline 3 & Lokbuntar & 60 & 225 & \\
\hline 4 & Pengambau hilir luar & 25 & 111 & \\
\hline 5 & Pengambau hilir dalam & 60 & 195 & 2,137 \\
\hline \multicolumn{5}{|c|}{ Batu benawa subdistrict } \\
\hline 1 & Aluan besar & 135 & 596 & \\
\hline 2 & Paya & 175 & 632 & 1,228 \\
\hline \multicolumn{5}{|c|}{ Pandawan subdistrict } \\
\hline 1 & Masiraan & 177 & 482 & \\
\hline 2 & Pelajau & 141 & 426 & 908 \\
\hline \multicolumn{5}{|c|}{ Barabai subdistrict } \\
\hline 1 & Barabai utara & 175 & 533 & \\
\hline 2 & Barabai selatan & 118 & 364 & \\
\hline 3 & Barabai darat & 552 & 943 & \\
\hline 4 & Barabai timur & 275 & 691 & \\
\hline 5 & Barabai barat & 394 & 766 & \\
\hline 6 & Pajukungan & 269 & 578 & \\
\hline 7 & Bukat & 319 & 772 & 4,647 \\
\hline \multicolumn{2}{|r|}{ Total } & 3,299 & 8,920 & \\
\hline
\end{tabular}

Source: BPBD, 2015

Presentation of information through Geografic Information System (GIS) is becoming the main runway used as a means to present information related to spatial data and other supporting data of information delivery. Application of GIS is the right step for mapping the area determining of agricultural land designation in the flood hazard area. GIS technology integrates data processing operations of database that is commonly used today, such as taking a typical visualization and various advantages offered by geographic analysis through images of webbased maps. Geographic Information System is a combination of database management in collecting and storing a large number of geospatial data, together with the ability of spatial analysis to determine the geospatial relationship between entities of each data used, added with a screen map that has a function to describe the relationship of geospatial data in two and three dimensions in the form of maps (Nyerges, 2009).

This study was carried out to perform Agricultural Land Mapping in Flood Hazard Areas in Hulu Sungai Tengah. The results of the mapping can be used as information retrieval for Policy Analysis of Integrated
Agricultural Division. GIS applications drafted using ArcView 32 and Arc GIS for flood hazard mapping and agricultural land mapping.

\section{MATERIALS AND METHODS}

Data collection methods used were field research and literature (library research). Data were analyzed using quantitative and qualitative approaches (mixed methods), with the techniques of scoring, SWOT, and spatial analysis (ArcView 3.2 software). The map of agricultural lands in flood hazard areas was obtained from overlay of some multiple base maps and the results of field measurements, as well as by scoring and overlay buffer of main rivers, slopes, elevations and land uses.

Having obtained the map of agricultural lands on flood hazard areas as the results of overlay of each factor, the next step was to validate the results of overlay with the actual conditions in the study area. The validation was performed by conducting interviews to stakeholders by asking the mapping results to the conditions in the study area. 


\section{RESULTS AND DISCUSSION}

\section{Flood Hazard Mapping}

Danger is a natural or artificial phenomenon that has a potential to threaten human life, loss of property and damage of environment (Prih Harjadi, 2007). The process of flood hazard mapping was made based on several variables by weighting and scoring (Nanik Suryo H et al., 2012). The weight of each flood variable was determined using a composite manner of each flood variable, which is often called with the terms CMA (Composite Mapping Analysis) (Anditha $\mathrm{H}$ et al., 2008). The flood hazard map was obtained by scoring and overlay buffer of the main rivers, slopes, elevations and land uses.

The results of the main stream buffer were divided by different ranges of distance, namely 0-300 m, 300-600 m, 600-900 m, and $>900 \mathrm{~m}$ from the main river based on the classification of BNPB (2011). Slope map was created using analysis of Triangle Interpolation Network (TIN) which was then classified based on the classification of slope according to Van Zuidam (1979). The next map was an Altitude Map and Land Use Map. The scores of Altitude Map and Land Use Map were based on Afrizal T et al., 2013.

The four parameters were used to determine the flood hazard areas around the main river. After each variable had a weight, the weighted overlay method / overlaying system of flood hazard variable was performed. Furthermore, after having obtained a Flood Hazard Map, the next step was to validate the results of overlay with the actual conditions in the study area. Validation was done by conducting interviews to stakeholders by asking potential flood hazard map to the conditions in the study area (see Table 2, Table and Figure 1). Flood hazard levels of most regions in Hulu Sungai Tengah were categorized into no hazard $\left(957.36 \mathrm{~km}^{2}\right)$, low hazard $\left(243.82 \mathrm{~km}^{2}\right)$, medium hazard $\left(455.01 \mathrm{~km}^{2}\right)$, and high hazard (114.91 km2).

\section{Agricultural Land Mapping (Rice Field) based on Land Use Map}

Land use can be defined as human intervention on the land, either permanently or periodically to meet the needs of both material and spiritual life (Arsyad, 1989, Talkurputra, et.al., 1996). Land use can be classified into two major categories, namely agricultural land use and non-agricultural land use. The agricultural land use is distinguished broadly into the kinds of land use based on the provision of water and cultivated land. The kinds of agricultural land use are rice fields, fields, orchards, mixed orchards, plantations, and forests. Non-agricultural land use can be distinguished into town or village (residential), industrial, and recreational uses (Arsyad, 2000).

The agricultural land use in Hulu Sungai Tengah includes forests, rice fields, plantations, fields, shrub, wasteland, swamps and waters. While the non-agricultural land use is a settlement. Land use mapping of an area is an attempt to collect, analyze, and classify the data of land use of an area concerned and to put it in the form of a map in a certain method so that the resulting map can be easily understood, provide a clear picture and be actually neat and clean (Sandy \& I Made, 1973).

Table 2 Flood Hazard Level in the Areas of Hulu Sungai Tengah Regency

\begin{tabular}{|c|c|c|c|c|c|c|c|c|c|}
\hline \multirow{2}{*}{ Subdistrict } & \multirow{2}{*}{$\begin{array}{c}\text { width } \\
\text { of } \\
\text { subdistrict } \\
\left(\mathrm{km}^{2}\right)\end{array}$} & \multicolumn{8}{|c|}{ Width $\left(\mathrm{km}^{2}\right)$ and presentation of flood hazard level } \\
\hline & & $\begin{array}{c}\text { no } \\
\text { hazard }\end{array}$ & $\%$ & $\begin{array}{c}\text { Low } \\
\text { hazard }\end{array}$ & $\%$ & $\begin{array}{l}\text { Medium } \\
\text { hazard }\end{array}$ & $\%$ & $\begin{array}{c}\text { High } \\
\text { hazard }\end{array}$ & $\%$ \\
\hline Barabai & 40.67 & - & - & 0.16 & 0.40 & 30.53 & 75.07 & 9.98 & 24.53 \\
\hline Batang Alai Selatan & 76.16 & 11.82 & 15.52 & 33.94 & 44.56 & 27.25 & 35.78 & 3.15 & 4.14 \\
\hline Batang Alai Timur & 778.80 & 734.34 & 94.29 & 39.00 & 5.01 & 5.45 & 0.70 & 0.01 & 0.00 \\
\hline Batang Alai Utara & 65.30 & - & - & 26.07 & 39.92 & 30.75 & 47.09 & 8.48 & 12.98 \\
\hline Batu Benawa & 54.45 & 8.09 & 14.86 & 19.56 & 35.92 & 19.22 & 35.30 & 7.58 & 13.92 \\
\hline Hantakan & 208.72 & 160.98 & 77.13 & 42.14 & 20.19 & 5.42 & 2.60 & 0.18 & 0.09 \\
\hline Haruyan & 101.41 & 34.44 & 33.96 & 30.33 & 29.91 & 30.17 & 29.75 & 6.48 & 6.39 \\
\hline Labuan Amas Selatan & 97.83 & - & - & 0.72 & 0.73 & 92.68 & 94.73 & 4.44 & 4.54 \\
\hline Labuan Amas Utara & 170.57 & - & - & - & - & 115.19 & 67.53 & 55.38 & 32.47 \\
\hline Limpasu & 61.12 & 7.68 & 12.57 & 51.90 & 84.91 & 1.54 & 2.52 & - & - \\
\hline Pandawan & 116.05 & - & - & - & - & 96.81 & 83.43 & 19.23 & 16.57 \\
\hline & $1,771.09$ & 957.36 & & 243.82 & & 455.01 & & 114.91 & \\
\hline
\end{tabular}

Source: Map of Flood Hazard Levels of Hulu Sungai Tengah Regency, 2016. 


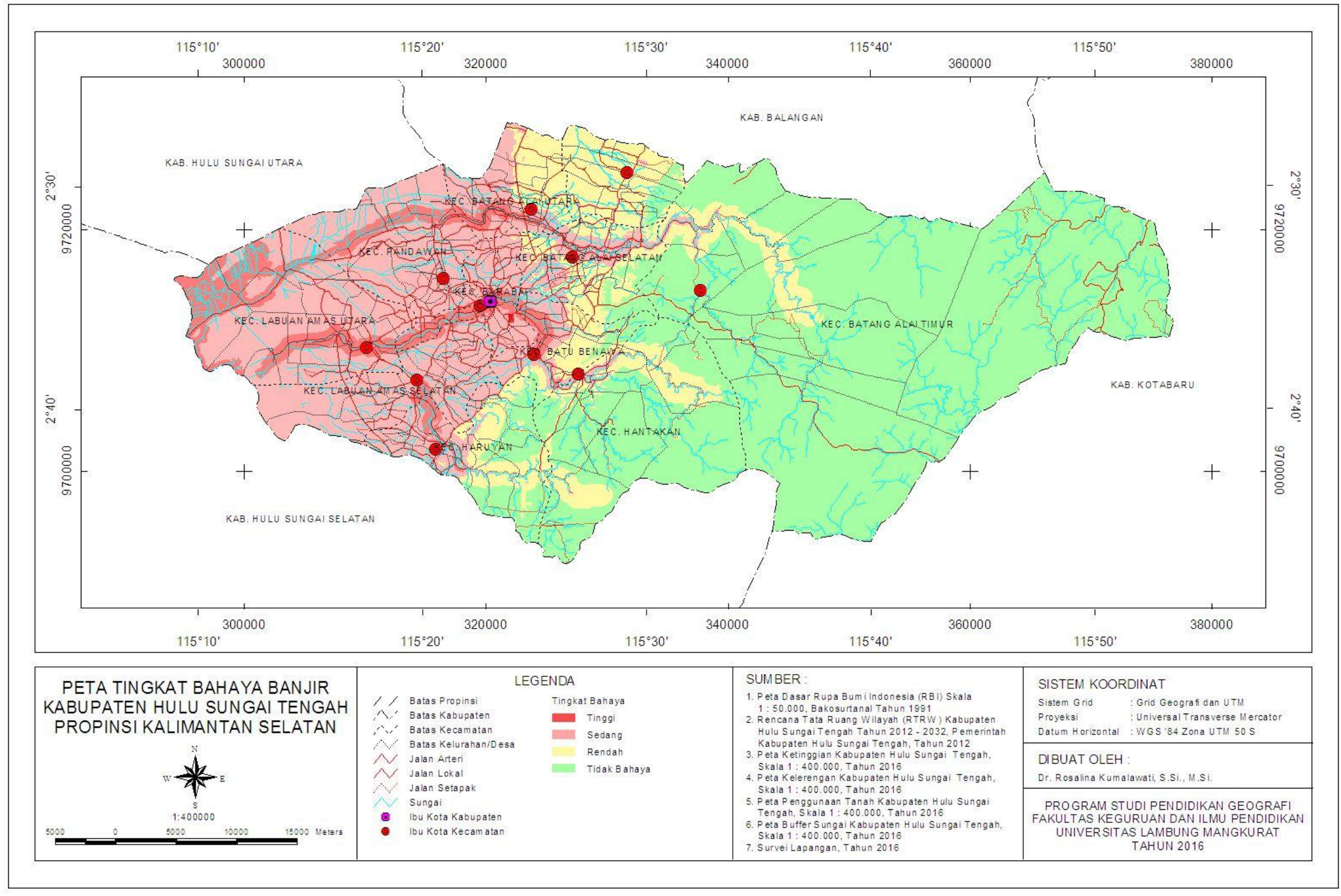

Figure 1 Map of Flood Hazard Areas, Hulu Sungai Tengah Regency 
Map of agricultural lands in Hulu Sungai Tengah Regency can be seen from the land use. The land uses in the areas of Hulu Sungai Tengah Regency in general were still dominated by local shrubs $(32.45 \%)$, forests (27.30\%) and rice fields (21.30\%). The land use for rice fields had the most extensive when compared to other agricultural land use. But when compared with the general land use it was not too big but still had a considerable role in the economy there. Rice field has another function in addition to its function as the main livelihood of the population, namely as the major supporter of economic system in Hulu Sungai Tengah Regency. Land use in the areas of Hulu Sungai Tengah Regency can be seen in Table 3 and Figure 2.

Table 3 Land Use in the Areas of Hulu Sungai Tengah Regency

\begin{tabular}{|c|c|c|c|c|c|c|c|c|c|c|c|c|c|c|c|c|c|c|c|c|}
\hline \multirow[b]{2}{*}{ NO } & \multirow[b]{2}{*}{ District } & \multicolumn{18}{|c|}{ Width $\left(\mathrm{Km}^{2}\right)$ and Persentation of Land Use } & \multirow[b]{2}{*}{ 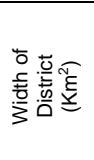 } \\
\hline & & 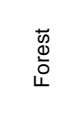 & $\%$ & 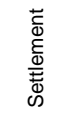 & $\%$ & 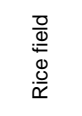 & $\circ$ & $\begin{array}{l}\frac{}{0} \\
\stackrel{\frac{\pi}{0}}{\frac{\pi}{0}} \\
\frac{\pi}{0}\end{array}$ & $\circ$ & $\frac{\overline{0}}{\frac{0}{2}}$ & $\circ$ & 产 & $\circ$ & $\begin{array}{l}\frac{0}{0} \\
\frac{\pi}{0} \\
\frac{0}{0} \\
\frac{\pi}{\pi} \\
3\end{array}$ & $\%$ & 苞 & $\circ$ & $\frac{\frac{\omega}{\omega}}{\frac{\pi}{\omega}}$ & $\%$ & \\
\hline 1 & Barabai & - & - & 9.13 & 0.52 & 26.20 & 1.48 & - & - & 4.96 & 0.28 & - & - & - & - & - & - & 0.38 & 0.02 & 40.67 \\
\hline 2 & Batang Alai Selatan & - & - & 6.77 & 0.38 & 34.23 & 1.93 & - & - & 14.68 & 0.83 & 19.66 & 1.11 & - & - & - & - & 0.83 & 0.05 & 76.16 \\
\hline 3 & Batang Alai Timur & 453.10 & 25.58 & 1.43 & 0.08 & 0.28 & 0.02 & - & - & 71.48 & 4.04 & 250.01 & 14.12 & 0.42 & 0.02 & - & - & 2.09 & 0.12 & 778.80 \\
\hline 4 & Batang Alai Utara & - & - & 5.19 & 0.29 & 32.35 & 1.83 & 8.19 & 0.46 & 6.82 & 0.38 & 12.26 & 0.69 & - & - & - & - & 0.49 & 0.03 & 65.30 \\
\hline 5 & Batu Benawa & - & - & 3.82 & 0.22 & 18.33 & 1.03 & - & - & 10.47 & 0.59 & 21.28 & 1.20 & - & - & - & - & 0.56 & 0.03 & 54.45 \\
\hline 6 & Hantakan & 30.49 & 1.72 & 3.88 & 0.22 & 1.13 & 0.06 & - & - & 18.84 & 1.06 & 153.12 & 8.65 & - & - & - & - & 1.26 & 0.07 & 208.72 \\
\hline 7 & Haruyan & - & - & 5.84 & 0.33 & 28.54 & 1.61 & - & - & 14.30 & 0.81 & 52.74 & 2.98 & - & - & - & - & - & & 101.41 \\
\hline 8 & $\begin{array}{l}\text { Labuan Amas } \\
\text { Selatan }\end{array}$ & - & - & 7.66 & 0.43 & 66.28 & 3.74 & - & - & 15.89 & 0.90 & 7.08 & 0.40 & - & - & 0.34 & 0.02 & 0.58 & 0.03 & 97.83 \\
\hline 9 & Labuan Amas Utara & - & - & 6.96 & 0.39 & 72.71 & 4.11 & - & - & 24.85 & 1.40 & 34.93 & 1.97 & - & - & 26.91 & 1.52 & 4.21 & 0.24 & 170.57 \\
\hline 10 & Limpasu & - & - & 2.55 & 0.14 & 21.75 & 1.23 & 8.70 & 0.49 & 6.58 & 0.37 & 20.83 & 1.18 & 0.39 & 0.02 & - & - & 0.32 & 0.02 & 61.12 \\
\hline \multirow[t]{2}{*}{11} & Pandawan & - & - & 11.11 & 0.63 & 75.49 & 4.26 & - & - & 25.84 & 1.46 & 2.84 & 0.16 & - & - & - & - & 0.77 & 0.04 & 116.05 \\
\hline & & 483.59 & 27.30 & 64.35 & 3.63 & 377.29 & 21.30 & 16.90 & 0.95 & 214.69 & 12.12 & 574.73 & 32.45 & 0.80 & 0.05 & 27.25 & 1.54 & 11.49 & 0.65 & $1,771.09$ \\
\hline
\end{tabular}

Source: Map Processing of Land Use, 2016.

The agricultural land use especially rice field in Hulu Sungai Tengah Regency was available in all subdistricts. Rice fields were available in all subdistricts, proving that the rice fields had an important role in the economy. Subdistricts with the most extensive agricultural land use were Pandawan, Labuan Amas Utara, and Labuan Amas Selatan subdistricts.

Agricultural sector has an important role in the economy and community survival, particularly its contribution to employment and domestic food. Agriculture is a sector of an integral part of regional development. Agriculture has two benefits to the poor, especially creating alternative employment and creating better access to food (Galuh, 2013; Beatly, 2000). The development of food crops is now so closely associated with the problem of utilization of land, changing of agricultural land use which would threaten the width of agricultural production land along with the increasing of regional development. The growing need for life and good agricultural land use for the purposes of agricultural production and uses in other fields requires planning and decision making policies for the most optimal utilization (Kubelaborbir, 2010). Land use in the agricultural sector often competes with other sectors such as industrial, residential and trade sectors.

Having found out the distribution of agricultural land use, especially rice fields in Hulu Sungai Tengah Regency, the amount of production can be identified. The amount of production can be correlated with the number of existing population. Furthermore, the nutritional adequacy rate of each subdistrict can be calculated, related to the needs of existing food materials. The surplus subdistricts and minus or deficient subdistricts can provide food items to each other without buying them from outside the area to fulfill the food demands.

Hulu Sungai Tengah Regency, which consists of 11 subdistricts, is an area with a quite great number of people. The more the number of population in an area, the more the demand for food. Proper planning is required to manage agricultural lands located in flood hazard areas. Selection of types of rice plants should also be adapted to the flood hazard areas. 


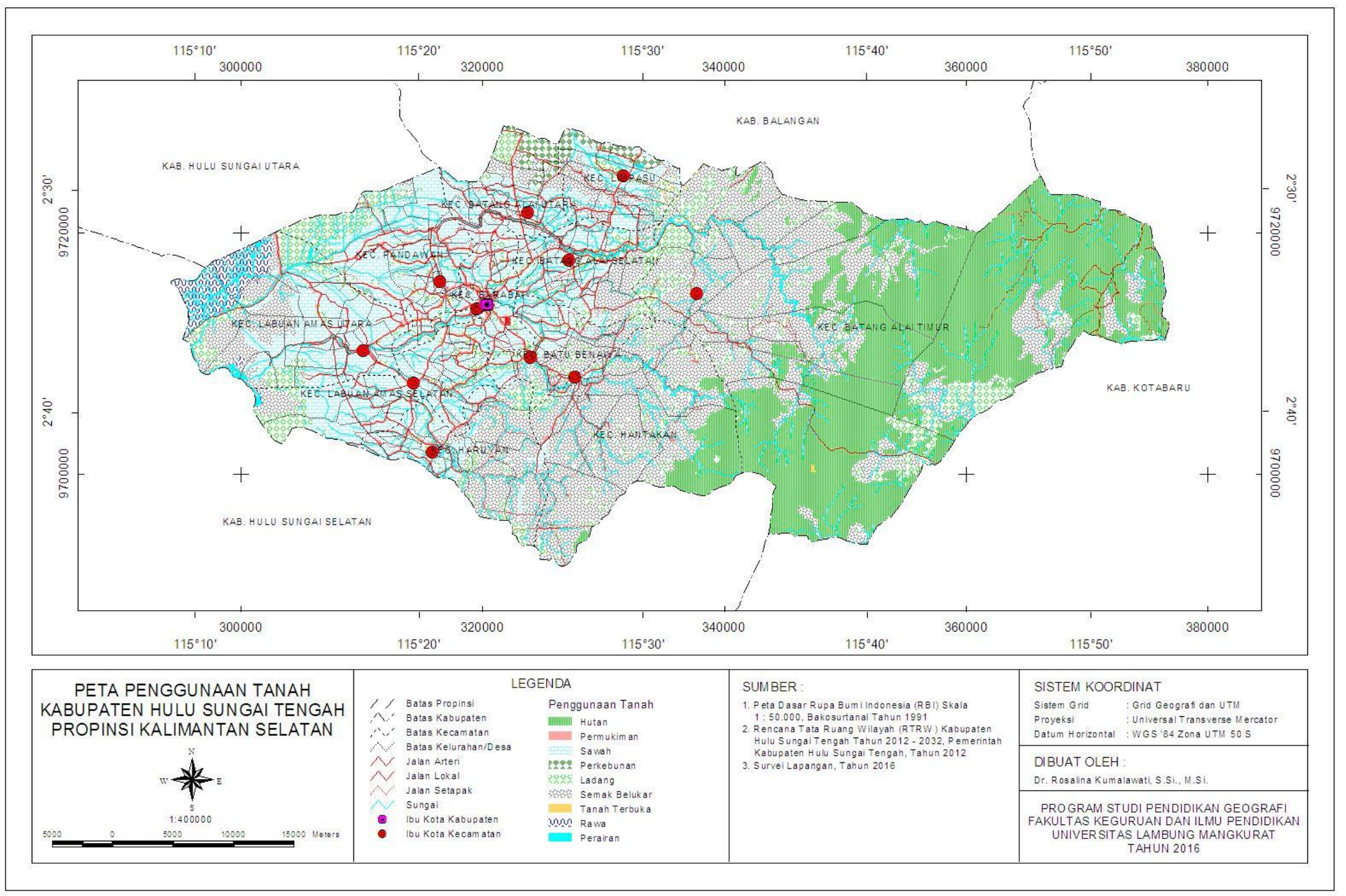

Figure 2 Map of Land Use in Hulu Sungai Tengah Regency 


\section{CONCLUSIONS}

The agricultural land use (rice field) in Hulu Sungai Tengah Regency was available in all subdistricts and flood hazard areas. It indicated that the rice fields had an important role in the economy of the regency. Subdistricts with the most extensive agricultural land use were Pandawan, Labuan Amas Utara, and Labuan Amas Selatan subdistricts.

\section{REFERENCES}

Chang, G. \& Canedy, L. (2011). Web-based GIS in tourism information search: Perceptions, tasks, and trip attributes. Journal of Tourism Management 32 : 1435-1437.

Indradewa M. S. 2008. Potential and flood disaster relief efforts of wolowona, nangaba and Kaliputih Rivers in Ende Regency. Study Program of Environmental Science, Postgraduate Program of Sebelas Maret University Surakarta.

Indraprahasta, G. S. (2013). The potential of urban agriculture development in Jakarta. Journal of Procedia Environmental Sciences 17: 11-19. Beatly T. Green urbanism: Learning from European cities.

Indrianawati, D. \& Hakim, A. M. (2013). Preparation of Database to Identify the Flood Prone Areas associated with Spatial Data Infrastructure Case Study: West Java Province. Journal of Itenas Engineer XVII (1). CLPPM Itenas. ISSN: 1410-3125 January 2013.

Kumalawati, R. \& Rijal, S.S. (2015). Evaluation of Regional Development of Settlements in the Areas of Flood Risk, Barabai District, Hulu Sungai Tengah Regency, South Kalimantan. Proceedings of the National Conference III. Built Environmental Innovation: "Restoration of Rural and City Settlement". Faculty of Civil Engineering and UII Planning. Yogyakarta.

Kumalawati, R. \& Rijal, S.S. (2015). Evaluation Factors Causing Floods of Community Based in Flood Risk Areas, Barabai District, Hulu Sungai Tengah Regency, South Kalimantan. Proceedings of the
National Seminar. Regional Independence in Disaster Mitigation Towards Sustainable Development. Surakarta: Postgraduate Program of PKLH FKIP, University of Sebelas Maret with the Association of Indonesian Disaster Experts.

Kumalawati, R. (2015). Population Profile Analysis to Evaluation of Regional Development of Settlements in Hulu Sungai Tengah Regency, South Kalimantan. Proceedings of the National Seminar and PIT IGI XVIII. UNJ: IGI Center, UNJ and BIG.

Kumalawati, R. (2015). The Influence of Land Use toward Flood Risk based on Community Perception in Barabai, Hulu Sungai Tengah Regency, South Kalimantan. Proceedings of International Seminar of Etnopedagogi based Education. Study Program of Social Education, FKIP UNLAM. Banjarmasin.

Kodoatie, R. J. \& Sugiyanto (2002). Flood: Several Causes and its Control Method in Environmental Perspective. Student Book. ISBN. 9799483468, 9789799483461.

Kodoatie, R.J. \& Sjarief, R. (2006). Integrated Disaster Management. Yarsif Watampone Publisher, Jakarta.

Kubelaborbir, H. \& Yarangga, K. (2010). Agroecological Zone of Keerom Regency, Papua Province Based on Geographycal Information System Approach. Agricultural Journal 21 (1): 77-84

Nuarsa, I.W. (2005). Self-Learning to Analyze Spatial Data with Arcview GIS 3.3 for Beginner. PT. Media Komputindo. Jakarta.

Nyerges, T. (2009). Gis and Society, University of Washington, Seattle, WA, USA.

Okoye, C.B \& Ojeh, V.N. (2015). Mapping of Flood Prone Areas in Surulere, Lagos, Nigeria : A GIS Approach. Journal of Geographic Information System 7 (2015): 158-176. Published Online April 2015 in SciRes. Retrieved from http://www.scirp.org/journal/jgis http://dx.doi.org/10.4236/jgis.2015.7 2014

Purwandari, T., Pramono, H., Kingma, M. \& Nanette, C. (2011). A GIS Modelling Approach for Flood Hazard Assessment in Part of Surakarta 
City, Indonesia. ISSN 0024-9521. Indonesian Journal of Geography 43 (1) (June 2011): 63-80.

Sakijege, T. (2013). Managing Flood Risks: Lesson From Keko Machungwa Informal Settelment in Dar Es Salaam, Tanzania. Indonesian Journal of Geography 45 (1) (June 2013): 1-14. ISSN 0024-9521.

Septriyadi, R. \& Hamhaber, J. (2013). Hazard Assessment to Tidal Flood Inundation (Case Study Tegal Municipality). Indonesian Journal of Geography 45 (1) (June 2013): 24 37. ISSN 0024-9521.

Simao, A., Denshamd, J. \& Haklay, P.M. (2009). Web-based GIS for collaborative planning and public participation: An application to the strategic planning of wind farm sites. Journal of Environmental Management 90: 2027 - 2040.

Tarigan, R. (2005). Area Development Planning. Bumi Aksara. Jakarta.

Tondobala, L. 2011. Understanding on Disaster Risk Areas and Observation toward Related Policies and Rules. Sabua Journal 3 (1) (Mei 2011): 58-63. ISSN 2085-7020. In Study Program of Area and City Planning, Major of Architecture, Engineering Faculty - University of Sam Ratulangi Manado.

UN-Habitat. (2009). Planning for Sustainable Cities, Global Report on Human Settlements, United Nations Human Settlements Programme. Earthscan. London.

Vatsavai, R.R., Shekhar, S., Burk, T.E. \& Lime, S. (2006). Umn mapserver: A high performance, interoperable, and open source web mapping and geo-spatial analysis system. Geographic Information Science. pp. 400-417.

Washington D.C. Island Press (2000). Dao, H. G., Yang, Y., \& Amararatne Y., (2005). GIS for land evaluation for shrimp farming in Haiphong of Vietnam. Journal of Ocean \& Coastal Management 48:51 - 63.

Widiarto, L.A., \& Kingma, N. (2014). Agricultural Loss Caused by 2007 Sidoharjo's Flood and its Houesehold Impacts. Indonesian Journal of Geography 46 (2) (December 2014): 156 - 166. ISSN 0024-9521.
Zhang, N., Runquist, R., Schrock, M., Havlin, J., Kluitenburg, G., \& Redulla, R. (1999). Making GIS a versatile analytical tool for research inprecision farming. Journal of Computers and Electronicsin Agriculture 22: 221 - 231. 